PREPARED IN COOPERATION WITH THE COMMONWEALTH OF MASSACHUSETTS

DEPARTMENT OF PUBLIC WORKS

\title{
AEROMAGNETIC MAP OF PART OF THE MARBLEHEAD NORTH QUADRANGLE, ESSEX COUNTY, MASSACHUSETTS
}

GEOPHYSICAL INVESTIGATIONS

MAP GP- 723

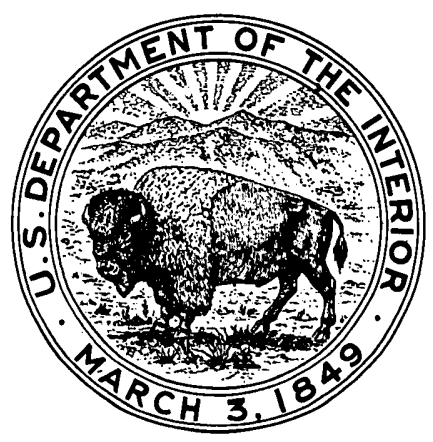

PUBLISHED BY THE U.S. GEOLOGICAL SURVEY 